\title{
Bevacizumab inhibits proliferation of choroidal endothelial cells by regulation of the cell cycle
}

\author{
Raluca Rusovici \\ Chirag J Patel \\ Kakarla V Chalam \\ University of Florida, Department \\ of Ophthalmology, Jacksonville, \\ FL, USA
}

\author{
This article was published in the following Dove Press journal: \\ Clinical Ophthalmology \\ 12 February 2013 \\ Number of times this article has been viewed
}

Correspondence: Kakarla V Chalam University of Florida, Department of Ophthalmology, 580 West 8th Street, Tower II, 3rd Floor, Jacksonville,

FL 32209, USA

Tel + I 904244936 I

$\mathrm{Fax}+$ I 904244939 I

Email kchalam@jax.ufl.edu
Background: The purpose of this study was to evaluate cell cycle changes in choroidal endothelial cells treated with varying doses of bevacizumab in the presence of a range of concentrations of vascular endothelial growth factor (VEGF). Bevacizumab, a drug widely used in the treatment of neovascular age-related macular degeneration, choroidal neovascularization, and proliferative diabetic retinopathy, neutralizes all isoforms of VEGF. However, the effect of intravitreal administration of bevacizumab on the choroidal endothelial cell cycle has not been established.

Methods: Monkey choroidal endothelial (RF/6A) cells were treated with VEGF $50 \mathrm{ng} / \mathrm{mL}$ and escalating doses of bevacizumab $0.1-2 \mathrm{mg} / \mathrm{mL}$ for 72 hours. Cell cycle changes in response to bevacizumab were analyzed by flow cytometry and propidium iodide staining. Cell proliferation was measured using the WST-1 assay. Morphological changes were recorded by bright field cell microscopy.

Results: Bevacizumab inhibited proliferation of choroidal endothelial cells by stabilization of the cell cycle in G0/G1 phase. Cell cycle analysis of VEGF-enriched choroidal endothelial cells revealed a predominant increase in the $\mathrm{G} 2 / \mathrm{M}$ population $(21.84 \%, P<0.01)$ and a decrease in the G0/G1 phase population $(55.08 \%, P<0.01)$. Addition of escalating doses of bevacizumab stabilized VEGF-enriched cells in the G0/G1 phase $(55.08 \%, 54.49 \%, 56.3 \%$, and $64 \%$ $[P<0.01])$ and arrested proliferation by inhibiting the $\mathrm{G} 2 / \mathrm{M}$ phase $(21.84 \%, 21.46 \%, 20.59 \%$, 20.94\%, and $16.1 \%[P<0.01]$ ). The increase in GO/G1 subpopulation in VEGF-enriched and bevacizumab-treated cells compared with VEGF-enriched cells alone was dose-dependent.

Conclusion: Bevacizumab arrests proliferation of VEGF-enriched choroidal endothelial cells by stabilizing the cell cycle in the G0/G1 phase and inhibiting the G2/M phase in a dosedependent fashion.

Keywords: bevacizumab, age-related macular degeneration, vascular endothelial growth factor

\section{Introduction}

Age-related macular degeneration (AMD) is the leading cause of irreversible blindness among patients over the age of 55 years in developed nations. Exudative AMD, a less common form of age-related macular degeneration, is characterized by formation of a choroidal neovascular membrane fibrovascular complex that emanates from the choriocapillaris through a defective Bruch's membrane. Exudation, hemorrhage, and subsequent detachment involving the neurosensory retina and retinal pigment epithelium are often associated with the neovascular process. Vascular endothelial growth factor (VEGF), a diffusible cytokine that induces epithelial cell proliferation and leakage, 
has been implicated as an important factor in this process. ${ }^{1,2}$ Inhibition of VEGF has become a widely accepted treatment for exudative AMD.

Bevacizumab, an anti-VEGF monoclonal antibody, is used intravitreally to inhibit choroidal endothelial cell proliferation associated with choroidal neovascularization. In vivo, the cell cycle of choroidal endothelial cells is under the influence of numerous growth factors present in the choroid, including vascular endothelial growth factor. ${ }^{3}$ Neither the amount of bevacizumab needed to inhibit proliferation of choroidal endothelial cells, nor the mechanism behind binding of bevacizumab to VEGF after intravitreal administration is known. In vitro, bevacizumab decreases VEGF-mediated monkey choroidal endothelial cell (RF/6A) proliferation. ${ }^{4}$

In this report, we investigated the effect of escalating doses of bevacizumab on the cell cycle dynamics of VEGFenriched proliferating choroidal endothelial cells. Our findings confirm RF/6A cell cycle stabilization in the G0/G1 phase after treatment with bevacizumab and subsequent inhibition of proliferation in a cell culture model.

\section{Materials and methods Cell culture}

RF/6A cells were obtained from the American Type Culture Collection (CRL-1780, Manassas, VA, USA) and were cultured in Eagle's minimal essential medium (Invitrogen, Carlsbad, CA, USA) containing 10\% fetal bovine serum (Sigma-Aldrich, St Louis, MO, USA), penicillin $100 \mathrm{U} / \mathrm{mL}$, and streptomycin $100 \mu \mathrm{g} / \mathrm{mL}$.

$\mathrm{RF} / 6 \mathrm{~A}$ cells were treated with human $\mathrm{VEGF}_{165}$ (Pepro Tech, Rocky Hill, NJ) $50 \mathrm{ng} / \mathrm{mL}$ and/or $0.1,1,1.5$ or $2 \mathrm{mg} / \mathrm{mL}$ of bevacizumab (Avastin ${ }^{\circledR}$, Genentech, South San Francisco, CA, USA), a recombinant humanized monoclonal antibody that inhibits the biologic activity of human VEGF for 72 hours.

\section{Cell growth assays}

For RF/6A cell growth assays, cells were plated at a density of 3000 cells/well in 96-well plates. Cellular proliferation was assessed according to the manufacturer's instructions with a 4-[3-(4-lodophenyl)-2-(4-nitrophenyl)-2H-5-tetrazolio]1.3-benzene disulfonate (WST-1) kit (Roche, Mannheim, Germany). The colorimetric assay is based on cleavage of the tetrazolium salt, WST-1, by mitochondrial dehydrogenases in viable cells. WST-1 solution (100 $\mu \mathrm{L} /$ well $)$ was added to cells in 96-well plates followed by incubation for 2 hours at $37^{\circ} \mathrm{C}$. The plate was read on a spectrophotometer at $440 \mathrm{~nm}$ with a reference wavelength at $690 \mathrm{~nm}$. Cells were treated with VEGF $50 \mathrm{ng} / \mathrm{mL}$ and/or different doses of bevacizumab $(0.1,1,1.5,2 \mathrm{mg} / \mathrm{mL})$ for 72 hours.

\section{Cell morphology}

Before exposure of the choroidal endothelial cells to bevacizumab, cellular morphology was recorded with bright field microscopy. Subsequently, cell morphology was assessed with an Olympus IX51 microscope 72 hours after incubation, with respective concentrations of VEGF $50 \mathrm{ng} / \mathrm{mL}$, bevacizumab $0.1,1,1.5,2 \mathrm{mg} / \mathrm{mL}$, and VEGF plus bevacizumab. Cells treated with hydrogen peroxide $1 \mathrm{mM}$ served as negative controls.

\section{Cell cycle analysis}

Choroidal endothelial cell cycle changes were assessed with flow cytometric evaluation of cells stained with propidium iodide (Sigma-Aldrich). For the flow cytometry assays, 100,000 cells/well were plated in six-well plates. The cells were allowed to attach for 24 hours. The cells were treated with varying concentrations of bevacizumab $(0.1$, $1.0,1.5,2 \mathrm{mg} / \mathrm{mL}$ ) and/or VEGF $50 \mathrm{ng} / \mathrm{mL}$ and incubated for another 72 hours. For flow cytometry assays using propidium iodide only, the cells were trypsinized and the pellet was resuspended in 70\% ethanol (Sigma-Aldrich) solution for 10 minutes at $4^{\circ} \mathrm{C}$. After centrifugation and subsequent washes with Hank's Balanced Salt Solution (Invitrogen), the pellet was resuspended in $10 \mu \mathrm{g} / \mathrm{mL}$ of propidium iodide solution and incubated at room temperature for 30 minutes in the dark.

Stained cells were analyzed on a Beckman Coulter (Fullerton, CA, USA) flow cytometer using excitation at $488 \mathrm{~nm}$ and emission at $600 \mathrm{~nm}$ for propidium iodide. Ten thousand cells were counted per sample, and the data were processed using standard software (Beckman Coulter or WINMDi 2.9). For each histogram obtained, gating was established to determine specific subpopulations based on their position in the cell cycle. Gates for flow cytometry analysis were established on control samples and were applied uniformly throughout for the other treatment groups. Serumstarved cells served as controls.

\section{Statistical analysis}

All experiments were done in at least triplicate. Statistical analysis amongst treatment groups was performed with analysis of variance (GraphPad, La Jolla, CA, USA). For the proliferation assays, two-tailed $t$-test analysis was used to determine $P$ values. Trend lines were determined using Excel (Microsoft, Redmond, WA, USA). 


\section{Results}

\section{Cell cytotoxicity: cell growth assays}

Proliferation rates in the treatment groups were quantified as percentages of control proliferation values (which were considered 100\%). Compared with controls, VEGF $50 \mathrm{ng} / \mathrm{mL}$ produced a $7.7 \%$ increase in proliferation of $\mathrm{RF} / 6 \mathrm{~A}$ cells $(P=0.04)$. Treatment with VEGF $50 \mathrm{ng} / \mathrm{mL}$ and bevacizumab $0.1 \mathrm{mg} / \mathrm{mL}$ produced a $24 \%$ decrease in $\mathrm{RF} / 6 \mathrm{~A}$ cell proliferation rates compared with controls $(P=0.03)$. At higher concentrations, bevacizumab $(1 \mathrm{mg} / \mathrm{mL}$ and $2 \mathrm{mg} / \mathrm{mL})$ induced a $12.1 \%$ and $10.2 \%$ decrease, respectively, in proliferation of RF/6A cells enriched with VEGF $50 \mathrm{ng} / \mathrm{mL}$ compared with controls $(P=0.02$ and $P=0.02$, respectively, Figure 1). Bevacizumab alone produced a decrease in $\mathrm{RF} / 6 \mathrm{~A}$ cell proliferation concentrations at doses of 0.1 , 1 , and $2 \mathrm{mg} / \mathrm{mL}(3.69 \%, 4.81 \%$, and $5.42 \%$, respectively, compared with control proliferation rates, $P=0.06, P=0.05$, and $P=0.05$, respectively).

\section{Cell cytotoxicity: morphology}

Cellular changes after treatment with bevacizumab $(0.1,1$, $1.5,2 \mathrm{mg} / \mathrm{mL}$ ) were assessed by bright field microscopy. The morphology of cells treated with bevacizumab and/or VEGF was unchanged compared with controls (Figure 2A and B). Cells maintained their polygonal shape and tight intercellular contacts with all treatments. Bright field microscopy of RF/6A cells in culture after 72 hours did not show cell membrane damage, a shrunken cytosol, or nuclear changes in the controls, VEGF, bevacizumab alone, or VEGF plus bevacizumab groups at any of the concentrations tested $(0.1,1,1.5,2 \mathrm{mg} / \mathrm{mL}$ bevacizumab, and VEGF $50 \mathrm{ng} / \mathrm{mL})$. In comparison, in negative controls, represented by cells treated with $1 \mathrm{mM}$ hydrogen peroxide treatment for 72 hours, we observed cellular debris and a few cells with shrunken cytoplasm.

\section{Cell cycle analysis: flow cytometry}

In cells under serum-starved conditions (representing the normal choroidal endothelial cell milieu), the percentage of cells in $\mathrm{G} 0 / \mathrm{G} 1$ phase was $70.39 \%$ (controls), in G2/M phase was $14.56 \%$, and in S phase was $11.32 \%$ (Table 1). In $\mathrm{RF} / 6 \mathrm{~A}$ cells treated with VEGF $50 \mathrm{ng} / \mathrm{mL}$, a decrease in the G0/G1 phase population (55.08\%) was observed. In VEGFtreated $\mathrm{RF} / 6 \mathrm{~A}$ cells, the percentage of cells in $\mathrm{S}$ phase was $14.9 \%$. VEGF $50 \mathrm{ng} / \mathrm{mL}$ increased the percentage of $\mathrm{RF} / 6 \mathrm{~A}$ cells in $\mathrm{G} 2 / \mathrm{M}$ phase $(21.84 \%$ versus $14.56 \%$ in controls, Figure $3 \mathrm{~A}$ and $\mathrm{B}$ ).

Compared with controls, a negative linear trend line was observed for the G0/G1 subpopulations of VEGF-enriched cells $\left(r^{2}=1 ; y=-15.317 x+85.713\right)$. Compared with controls, a positive linear trend was observed for the $\mathrm{G} 2 / \mathrm{M}$ subpopulations of VEGF-enriched cells $\left(r^{2}=1 ; y=7.28 x+7.28\right)$.

Addition of bevacizumab $(0.1,1,1.5,2 \mathrm{mg} / \mathrm{mL})$ to VEGF-enriched cells $(50 \mathrm{ng} / \mathrm{mL})$ produced an increased percentage of cells in the G0/G1state $(55.08 \%, 54.49 \%$, $56.3 \%$, and $64 \%$, respectively). VEGF $50 \mathrm{ng} / \mathrm{mL}$ and bevacizumab $(0.1,1,1.5,2 \mathrm{mg} / \mathrm{mL})$ produced dose-dependent decreased percentages of cells in the G2/M state compared

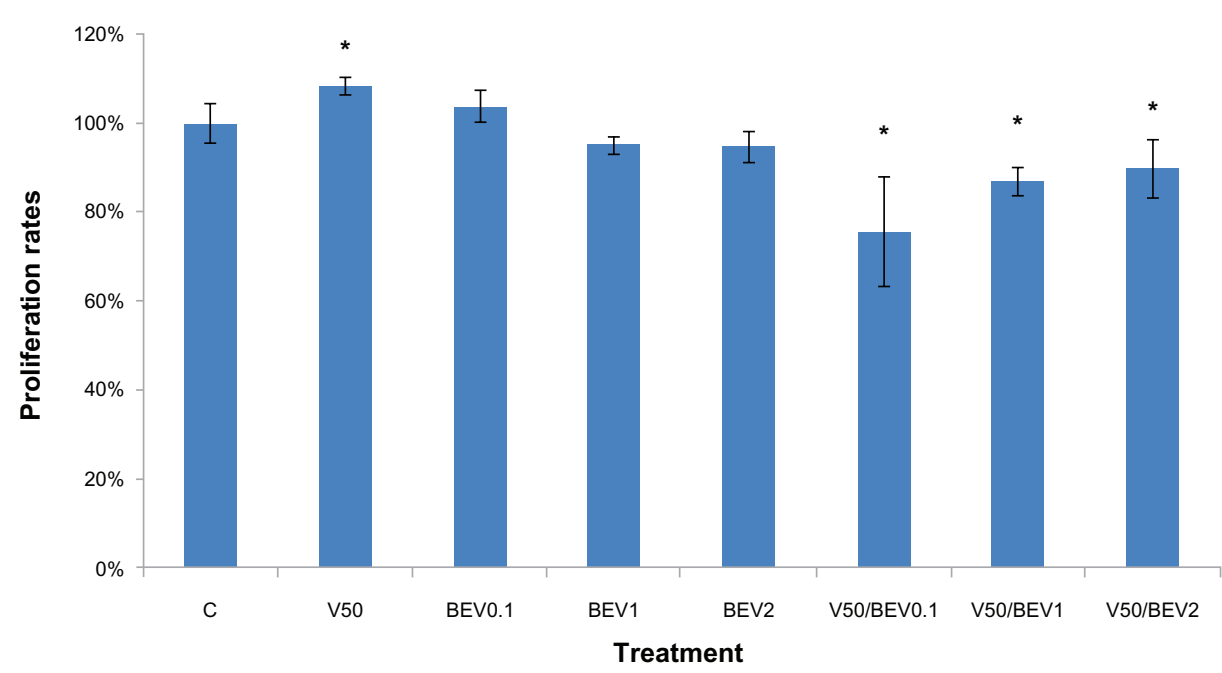

Figure I Proliferation of RF/6A cells in response to VEGF and bevacizumab.

Notes: Effect of different concentrations $(0.1-2 \mathrm{mg} / \mathrm{mL})$ of bevacizumab and/or VEGF $50 \mathrm{ng} / \mathrm{mL}$ on proliferation of RF/6A cells. Increasing concentrations of bevacizumab I-2 mg/mL produce a significant decrease in cell proliferation rate compared with controls. VEGF increases RF/6A proliferation rates as compared with controls. Cell proliferation was determined by the WST-I assay. Proliferation rates are expressed as percentages of control values. $* P<0.05$.

Abbreviations: BEV, bevacizumab; VEGF, vascular endothelial growth factor. 
A

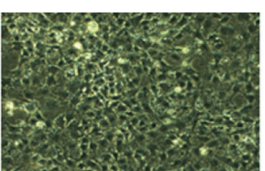

C

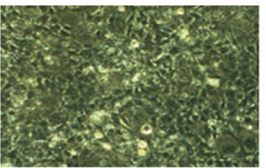

BEV0.1

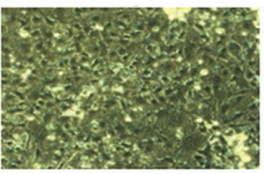

BEV2

B

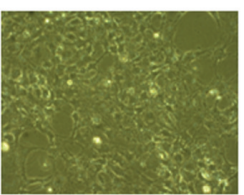

V50

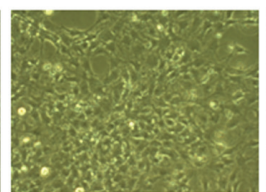

V50/BEV0.1

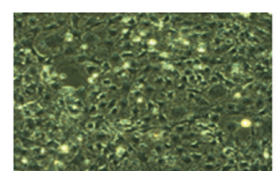

BEV1

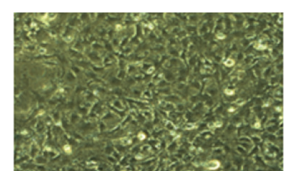

BEV1.5

C

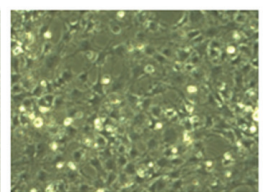

V50/BEV1

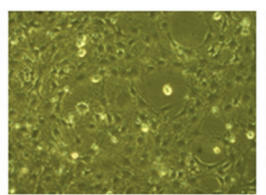

V50/BEV1.5

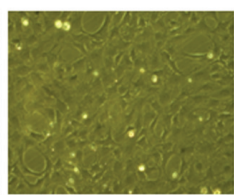

V50/BEV2

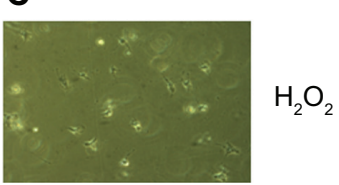

Figure 2 Morphology of RF/6A cells treated with bevacizumab and/or VEGF. (A) Effect of different concentrations of bevacizumab alone on RF/6A cell morphology. (B) Effect of different concentrations of bevacizumab and VEGF on RF/6A cell morphology. Photomicrographs showing no observable differences in morphology amongst different treatment groups and controls. Bright field images were taken at a $20 \times$ magnification. (C) Hydrogen peroxide-treated negative controls cells showed cellular remnants and a few viable cells.

Abbreviations: BEV, bevacizumab; VEGF, vascular endothelial growth factor.

with controls $(21.46 \%, 20.59 \%, 20.94 \%$, and $16.1 \%$, respectively). The highest increase in G0/G1 phase subpopulation occurred in cells treated with bevacizumab $2 \mathrm{mg} / \mathrm{mL}$ plus VEGF, where the G0/G1 phase population was $64 \%$ compared with $52 \%$ for VEGF-enriched cells (Figure 4A and $B)$. The increase in the G0/G1 subpopulation in VEGFenriched and bevacizumab-treated cells compared with VEGF-enriched cells was dose-dependent. VEGF $50 \mathrm{ng} / \mathrm{mL}$ and bevacizumab $(0.1,1,1.5,2 \mathrm{mg} / \mathrm{mL})$ did not alter the $\mathrm{S}$ phase population, with the exception of the VEGF and bevacizumab $2 \mathrm{mg} / \mathrm{mL}$ treatment groups (15.75\%, 16.03\%, $16.66 \%$, and $13.5 \%$, respectively, Figure $4 \mathrm{~A}$ and B). VEGF $50 \mathrm{ng} / \mathrm{mL}$ and bevacizumab $(0.1,1,1.5,2 \mathrm{mg} / \mathrm{mL})$ produced a positive linear increase in the subpopulation of G0/ G1 cells compared with VEGF-enriched cells $\left(\mathrm{r}^{2}=0.2854\right.$; $\mathrm{y}=1.4143 \mathrm{x}+50.4)$. Treatment with VEGF $50 \mathrm{ng} / \mathrm{mL}$ and bevacizumab $(0.1,1,1.5,2 \mathrm{mg} / \mathrm{mL})$ produced a linear decrease in $\mathrm{G} 2 / \mathrm{M}$ cell subpopulation percentages $\left(\mathrm{r}^{2}=0.455\right.$; $\mathrm{y}=-0.9608 \mathrm{x}+24.256)$. VEGF $50 \mathrm{ng} / \mathrm{mL}$ and bevacizumab $(0.1,1,1.5,2 \mathrm{mg} / \mathrm{mL})$ did not determine changes in $\mathrm{S}$ phase population percentages compared with control percentages $\left(r^{2}=0.0473 ; y=-0.164 x+16.308\right)$.

\section{Discussion}

AMD is the leading cause of severe vision loss and blindness in individuals over the age of 50 years, and affects 15 million North Americans. The exudative (or neovascular) variety accounts for approximately $10 \%$ of individuals with wet AMD. Exudative AMD is characterized by the presence of a neovascular complex resulting from a break in Bruch's membrane. The fibrovascular complex proliferates within the inner aspect of Bruch's membrane and destroys the

Table I Cell cycle analysis of RF/6A choroidal endothelial cells treated with bevacizumab and VEGF

\begin{tabular}{lll}
\hline Cell cycle phases & & \\
\hline Treatments & G0/G I & S + G2/M \\
\hline VEGF $(50 \mathrm{ng} / \mathrm{mL})$ & 55.08 & 36.74 \\
VEGF + BEV $(0.1 \mathrm{mg} / \mathrm{mL})$ & 55.08 & 37.21 \\
VEGF + BEV $(I \mathrm{mg} / \mathrm{mL})$ & 54.49 & 39.62 \\
VEGF + BEV $(I .5 \mathrm{mg} / \mathrm{mL})$ & 56.3 & 37.6 \\
VEGF + BEV $(2 \mathrm{mg} / \mathrm{mL})$ & 64 & 29.6 \\
\hline
\end{tabular}

Notes: Effect of different concentrations of bevacizumab and VEGF on cell cycle as quantified by flow cytometry. Gating was performed on DNA content plot graphs to measure percentages of cells in G0/GI, S, and G2/M subphases.

Abbreviations: BEV, bevacizumab; VEGF, vascular endothelial growth factor. 


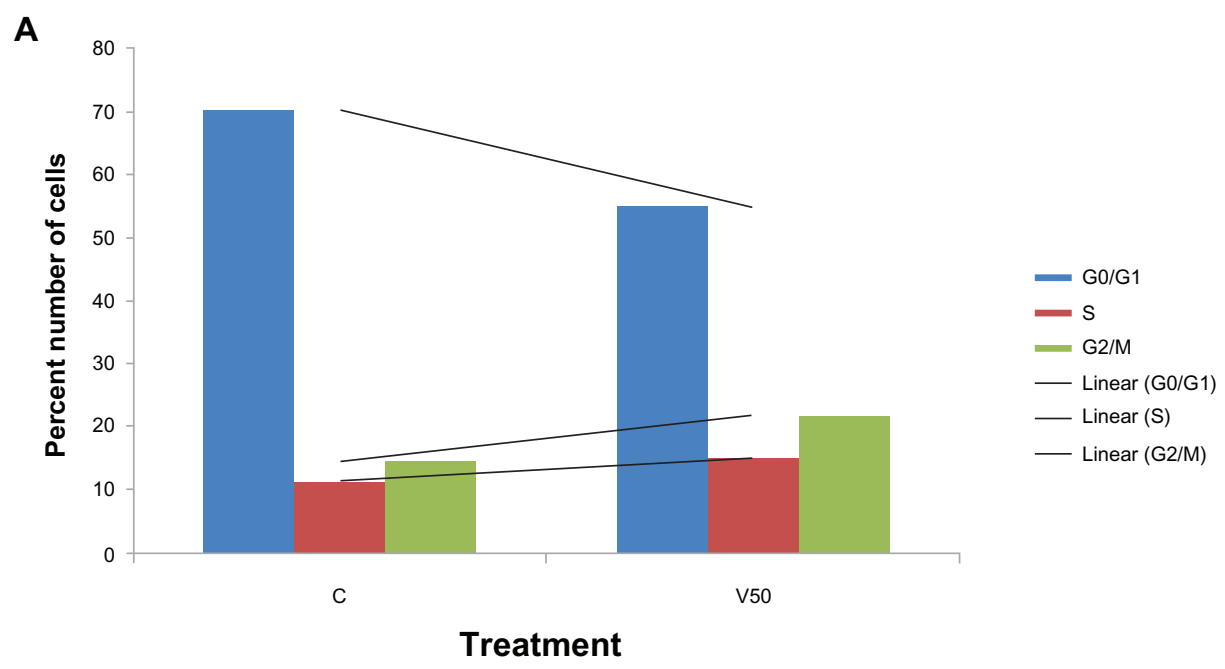

B
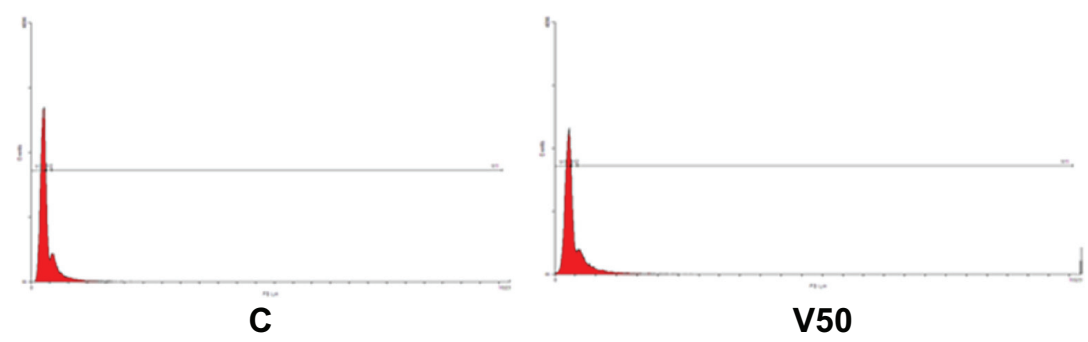

Figure 3 Cell cycle analysis of RF/6A choroidal endothelial cells under control or VEGF-enriched conditions. (A) Effect on cell cycle as quantified by flow cytometry. Flow cytometry analysis of control RF/6A or VEGF-treated cells. Cells were stained with propidium iodide prior to flow cytometry analysis. For analysis purposes, gating was performed on DNA content plot graphs to measure percentages of cells in G0/GI, S, and G2/M subphases. Gates were established on control samples and were maintained constant for the other treatment groups. (B) Representative DNA histograms showing phase cell cycle changes in response to treatment.

Abbreviation: VEGF, vascular endothelial growth factor.

normal architecture of the choriocapillaris, Bruch's membrane, retinal pigment epithelium, and outer retina. ${ }^{1,3,5,6}$

Histologically in exudative AMD, accumulation of drusen with concomitant thickening of the collagenous layers within Bruch's membrane creates a hydrophobic barrier impeding the passage of fluid and nutrients between the choroid and outer retina; therefore, an area of relative ischemia develops. ${ }^{1,3,5,6}$ Ischemia causes vasodilation of existing blood vessels and increased vascular permeability; in combination with an influx of growth-promoting and growth-inhibiting cytokines, choroidal endothelial cells proliferate and fracture in Bruch's membrane, providing a path for ingrowth of neovascular complexes. ${ }^{1,3}$ Although many cytokines are currently under investigation, VEGF appears to be the most important factor in initiating choroidal endothelial cell proliferation. ${ }^{3,4,7-9}$

Anti-vascular endothelial growth factor therapies are currently the mainstay of treatment for exudative AMD. Pegaptanib, ranibizumab, and bevacizumab are recognized modalities for inhibiting the effect of VEGF. Pegaptanib is an oligonucleotide aptamer that antagonizes the effect of VEGF and was one of the first compounds used to treat exudative AMD. Bevacizumab is a full-length monoclonal antibody to VEGF that is extensively used as an off-label treatment for macular edema and exudative AMD. AntiVEGF agents interfere with VEGF and inhibit the process of angiogenesis. ${ }^{10-14}$

Traditionally, the cell cycle is divided into four distinct phases, ie, G0, G1, S, G2, and M. Each phase involves numerous cytokines and cell signaling to serve as a series of checks and balances to ensure proper regulation of the cell cycle, thus ensuring balance of cell lines. The ubiquitin-proteasome system, through ubiquitination and deubiquitination, manages cell cycle progression between each phase, ensuring a unidirectional pathway to the cell cycle. ${ }^{15,16}$

A key regulating factor, known as hypoxia inducible factor (HIF)-1 $\alpha$, modulates angiogenesis by promoting mitogenic and migratory activities of endothelial cells. Two angiogenic factors, VEGF and angiopoetin-2, are dependently regulated by HIF- $1 \alpha$; in normal conditions, HIF- $1 \alpha$ is 
A

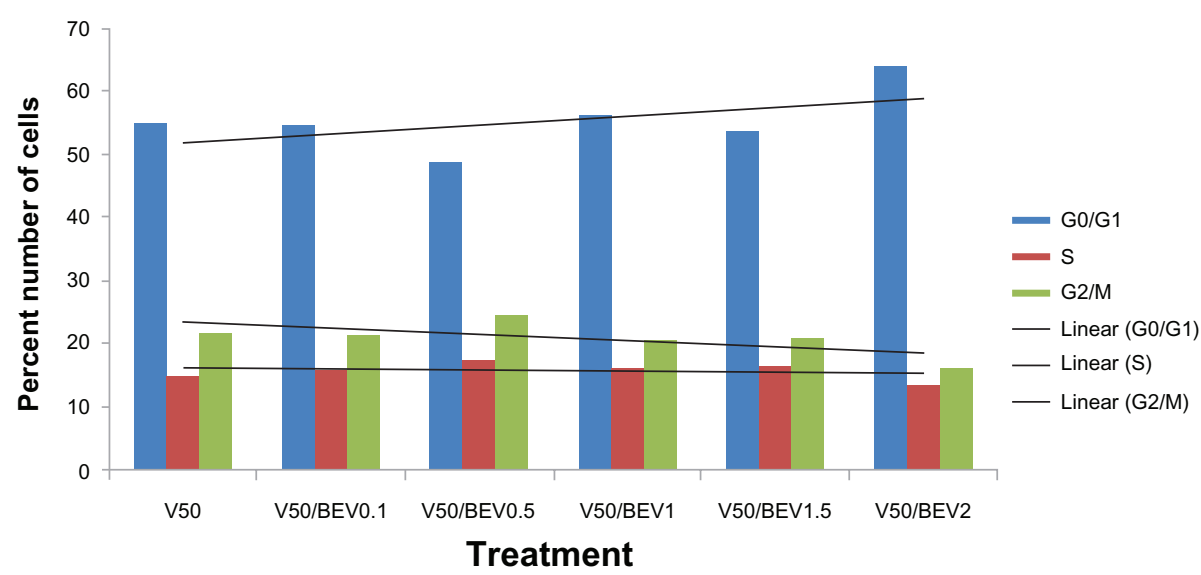

B
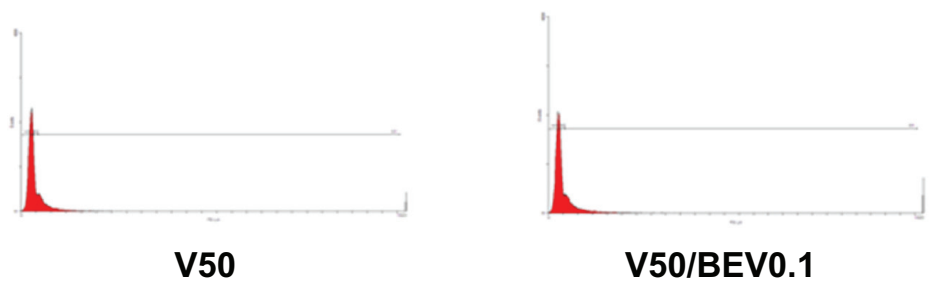

V50/BEV0.1

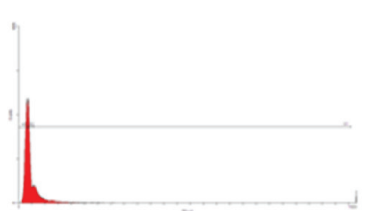

V50/BEV1

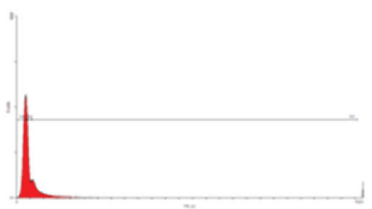

V50/BEV1.5

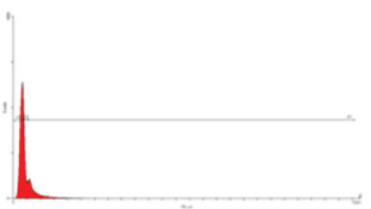

V50/BEV2

Figure 4 Cell cycle analysis of RF/6A choroidal endothelial cells treated with bevacizumab and VEGF. (A) Effect of different concentrations of bevacizumab and VEGF on cell cycle as quantified by flow cytometry. Flow cytometry analysis of RF/6A cells treated with bevacizumab. Cells were stained with propidium iodide prior to flow cytometry analysis. For analysis purposes, gating was performed on DNA content plot graphs showing percentage of cells G0/GI, S, and G2/M phases. Gates were established on control samples and were maintained constant for the other treatment groups. (B) Representative DNA histograms showing phase cell cycle changes in response to treatment. Abbreviations: BEV, bevacizumab; VEGF, vascular endothelial growth factor.

constantly degraded to modulate vascular growth. ${ }^{16}$ In stress conditions, such as hypoxia, ubiquitination of HIF- $1 \alpha$ enables heterodimerization with HIF-1 $\beta$ and subsequent attachment to hypoxic responsive elements within the promoter regions of target genes. HIF-1 $\alpha$ directly regulates hypoxia-induced activity of nitric oxide synthase, through binding sites with affinity to nitric oxide synthase in a wide range of cell types, including cardiac myocytes, endothelial, glioblastoma, and hepatoma cells. In turn, the nitric oxide produced promotes endothelial cell proliferation by inhibiting caspase-induced apoptosis. ${ }^{15,16}$

This study investigated the effect of increasing doses of bevacizumab on the cell cycle of VEGF-enriched proliferating choroidal endothelial cells. In our model, serum-starved choroidal endothelial cells served as control cells and represent stable choroidal endothelium; VEGF-enriched culture conditions represent active neovascularization. Addition of
VEGF increased proliferation rates of choroidal endothelial cells to $107.7 \%$. In the presence of bevacizumab, proliferation rates of VEGF-enriched cells decreased in a doseindependent fashion (range 10.2\%-24\%). Flow cytometric assays of untreated RF/6A cells demonstrate $60 \%$ in the $\mathrm{G} 0$ / G1 phase, $20 \%$ in the $\mathrm{S}$ phase, and $20 \%$ in the G2/M phase. ${ }^{17}$ In our study, flow cytometry results showed a significant shift in the proportion of cells from the G2/M phase to G0/ G1 phase after addition of bevacizumab to VEGF-enriched cells. Compared with VEGF-enriched only cells, the percentage of cells in the "resting" phase increased, while the percentage of cells in the "active" phase decreased in a dosedependent fashion. The highest increase in the G0/G1 phase subpopulation occurred in VEGF-enriched cells treated with bevacizumab $2 \mathrm{mg} / \mathrm{mL}$. Brar et al ${ }^{4}$ also reported a $29.7 \%$ increase in cell growth with addition of VEGF $50 \mathrm{ng} / \mathrm{mL}$. Although some studies exhibited VEGF-induced RF/6A 
cellular proliferation, the impact on cell cycle control was not evaluated..$^{8,9,18,19}$ Our study demonstrated a reduced rate of proliferation, with a higher percentage of cells in G0/G1 and a lower percentage of cells in G2/M upon addition of various concentrations of bevacizumab to VEGF-enriched cells. In ARPE-19 cells, bevacizumab produced a G1/S cell cycle arrest. ${ }^{20}$

Cell cycle inhibitors, such as p27 KIP, may be involved in the mechanism behind this effect. ${ }^{21}$ In fact, the addition of rosmarinic acid, a VEGF antagonist, had a similar effect on choroidal endothelial cells and produced G2/M cell cycle arrest with upregulation of p27 KIP. ${ }^{21}$ In summary, bevacizumab inhibits G2/M phase and arrests proliferation of VEGF-enriched choroidal endothelial cells by stabilizing the cell cycle in $\mathrm{G} 0 / \mathrm{G} 1$ phase in a dose-dependent manner.

\section{Disclosure}

The authors report no conflicts of interest in this work.

\section{References}

1. Ambati J, Ambati BK, Yoo SH, Ianchulev S, Adamis AP. Age-related macular degeneration: etiology, pathogenesis, and therapeutic strategies. Surv Ophthalmol. 2003;48:257-293.

2. Age-Related Eye Disease Study Research Group. The Age-Related Eye Disease Study (AREDS): design implications. AREDS report no 1. Control Clin Trials. 1999;20:573-600.

3. Citirik M, Kabatas EU, Batman C, Akin KO, Kabatas N. Vitreous vascular endothelial growth factor concentrations in proliferative diabetic retinopathy versus proliferative vitreoretinopathy. Ophthalmic Res. 2012;47:7-12.

4. Brar VS, Sharma RK, Murthy RK, Chalam KV. Evaluation of differential toxicity of varying doses of bevacizumab on retinal ganglion cells, retinal pigment epithelial cells, and vascular endothelial growth factor-enriched choroidal endothelial cells. J Ocul Pharmacol Ther. 2009;25:507-511.

5. Age-Related Eye Disease Study Research Group. A randomized, placebocontrolled, clinical trial of high-dose supplementation with vitamins $\mathrm{C}$ and $\mathrm{E}$, beta carotene, and zinc for age-related macular degeneration and vision loss: AREDS report no 8. Arch Ophthalmol. 2001;19: $1417-1436$

6. Bressler NM, Bressler SB. Preventative ophthalmology: age-related macular degeneration. Ophthalmology.1995;102:1206-1211.

7. Shimomura Y, Hirata A, Ishikawa S, Okinami S. Changes in choriocapillaris fenestration of rat eyes after intravitreal bevacizumab injection. Graefes Arch Clin Exp Ophthalmol. 2009;247:1089-1094.
8. McLaughlin AP, De Vries GW. Role of PLCgamma and $\mathrm{Ca}(2+)$ in VEGF- and FGF-induced choroidal endothelial cell proliferation. $\mathrm{Am}$ J Physiol Cell Physiol. 2001;281:1448-1456.

9. Zubilewicz A, Hecquet C, Jeanny JC, Soubrane G, Courtois Y, Mascarelli F. Two distinct signalling pathways are involved in FGF2stimulated proliferation of choriocapillary endothelial cells: a comparative study with VEGF. Oncogene. 2001;20:1403-1413.

10. Brown DM, Kaiser PK, Michels M, et al. ANCHOR study group ranibizumab vs verteporfin for neovascular age-related macular degeneration. N Engl J Med. 2006;355:1432-1444.

11. Fung AE, Lalwani GA, Rosenfeld PJ, et al. An optical coherence tomography-guided, variable dosing regimen with intravitreal ranibizumab (Lucentis) for neovascular age-related macular degeneration. Am J Ophthalmol. 2007;143:566-583.

12. Gragoudas ES, Adamis AP, Cunningham ET Jr, Feinsod M, Guyer DR; VEGF Inhibition Study in Ocular Neovascularization Clinical Trial Group. Pegaptanib for neovascular age-related macular degeneration. N Engl J Med. 2004;351:2805-2816.

13. Rosenfeld PJ, Brown DM, Heier JS, et al; MARINA Study Group. Ranibizumab for neovascular age-related macular degeneration. 2-year results of the MARINA study. $N$ Engl J Med. 2006;355:1419-1431.

14. Martin DF, Maguire MG, Ying GS, Grunwald JE, Fine SL, Jaffe GJ; CATT Research Group. Ranibizumab and bevacizumab for neovascular age-related macular degeneration. $N$ Engl J Med. 2011;364: 1897-1908.

15. Fasanaro P, Capogrossi MC, Martelli F. Regulation of the endothelial cell cycle by the ubiquitin-proteasome system. Cardiovasc Res. 2010;85: 272-280.

16. Liao D, Johnson RS. Hypoxia: a key regulator of angiogenesis in cancer. Cancer Metastasis Rev. 2007;26:281-290.

17. Amrite AC, Kompella UB. Celecoxib inhibits proliferation of retinal pigment epithelial and choroid-retinal endothelial cells by a cyclooxygenase2-independent mechanism. J Pharmacol Exp Ther. 2008;324: 749-758.

18. Geisen P, McColm JR, Hartnett ME. Choroidal endothelial cells transmigrate across the retinal pigment epithelium but do not proliferate in response to soluble vascular endothelial growth factor. Exp Eye Res. 2006;82:608-619.

19. Takeda A, Hata Y, Shiose S, et al. Suppression of experimental choroidal neovascularization utilizing KDR selective receptor tyrosine kinase inhibitor. Graefes Arch Clin Exp Ophthalmol. 2003;241:765-772.

20. Kuo CN, Chen CY, Lai CH, et al. Cell cycle regulation by bevacizumab in ARPE-19 human retinal pigment epithelial cells. Mol Med Report. 2012;6:701-704.

21. Kim JH, Lee BJ, Kim JH, Yu YS, Kim MY, Kim KW. Rosmarinic acid suppresses retinal neovascularization via cell cycle arrest with increase of p21 (WAF1) expression. Eur J Pharmacol. 2009;615:150-154.
Clinical Ophthalmology

\section{Publish your work in this journal}

Clinical Ophthalmology is an international, peer-reviewed journal covering all subspecialties within ophthalmology. Key topics include: Optometry; Visual science; Pharmacology and drug therapy in eye diseases; Basic Sciences; Primary and Secondary eye care; Patient Safety and Quality of Care Improvements. This journal is indexed on Submit your manuscript here: http://www.dovepress.com/clinical-ophthalmology-journal

\section{Dovepress}

PubMed Central and CAS, and is the official journal of The Society of Clinical Ophthalmology (SCO). The manuscript management system is completely online and includes a very quick and fair peer-review system, which is all easy to use. Visit http://www.dovepress.com/ testimonials.php to read real quotes from published authors. 